\title{
Kualitas Gel Pembersih Tangan (Handsanitizer) dari Ekstrak Batang Pisang dengan Penambahan Alkohol, Triklosan dan Gliserin yang Berbeda Dosisnya
}

\author{
Aminah Asngad, Aprilia Bagas R, Nopitasari \\ Prodi Pendidikan Biologi FKIP Universitas Muhammadiyah Surakarta \\ e-mail: aa125@ums.ac.id
}

\begin{abstract}
Abstrak
Antiseptik atau hand sanitizer bila digunakan terus menerus dapat berbahaya dan mengakibatkan iritasi hingga menimbulkan rasa terbakar pada kulit. Karena menggunakan alkohol dan triklosan yang merupakan bahan kimia. Salah satu upaya untuk mengurangi alkohol dan triklosan, maka dilakukan inovasi produk antiseptik handsanitizer dengan menggunakan ekstrak batang tanaman pisang yang mengandung senyawa antibakteri. Tujuan penelitian ini adalah untuk mengetahui untuk mengetahui kualitas handsanitizer dalam bentuk gel berbahan batang pisang dengan penambahan alkohol, triklosan dan gliserin yang berbeda dosisnya. Penelitian dilakukan di laboratorim Prodi Pendidikan Biologi FKIP UMS, metode penelitian eksperimen. Rancangan penelitian acak lengkap dengan 2 faktor perlakuan yaitu: Faktor 1 Perbandingan konsentrasi alkohol dan triklosan yakni $=2 \mathrm{ml}: 1,75 \mathrm{~g} ;=1 \mathrm{ml}: 1,5 \mathrm{~g}$. Faktor 2 Volume Gliserin = $4 \mathrm{ml} ;=$ $3 \mathrm{ml}$; = $2 \mathrm{ml}$. Analisis yang digunakan deskriptif kualitatif untuk Uji daya hambat bakteri dan untuk Uji Viskositas. Hasil penelitian menunjukkan Pada perlakuan dan paling efektif membunuh bakteri dibandingkan perlakuan yang lainnya. viskositas tertinggi terdapat pada perlakuandengan hasil uji viskositas sebesar 1250 cps. Berdasarkan hasil penelitian dapat diambil simpulan ada perbedaan kualitas handsanitizer dalam bentuk gel berbahan batang pisang dengan penambahan alkohol, triklosan dan gliserin yang berbeda dosisnya.
\end{abstract}

Kata Kunci: handsanitizer, batang pisang, Viskositas dan triklosan

\section{Pendahuluan}

Handsanitizer merupakan salah satu bahan antiseptik berupa gel yang sering digunakan masyarakat sebagai media pencuci tangan yang praktis. Penggunaan handsanitizer lebih efektif dan efisien bila dibanding dengan menggunakan sabun dan air sehingga masyarakat banyak yang tertarik menggunakannya.

Adapun kelebihan hand sanitizer dapat membunuh kuman dalam waktu relatif cepat, karena mengandung senyawa alkohol (etanol, propanol, isopropanol) dengan konsentrasi $\pm 60 \%$ sampai $80 \%$ dan golongan fenol (klorheksidin, triklosan). Senyawa yang terkandung dalam hand sanitizer memiliki mekanisme kerja dengan cara mendenaturasi dan mengkoagulasi protein sel kuman.
Alkohol sebagai disinfektan hanya mempunyai aktivitas bakterisidal saja, tetapi tidak terhadap virus dan jamur. Selain sebagai disinfektan, alkohol dalam Hand sanitizer dapat membantu melarutkan triklosan. Menurut hasil penelitian penelitian Rini (2018) bahwa antiseptik pada beberapa merk dengan kadar alkohol 60-70\% tanpa tambahan zat antibakteri lainnya memiliki sifat yang lebih polar, sehingga diameter daya hambat yang dihasilkan lebih besar pada bakteri Staphylococcus aureus.

Golongan fenol yang digunakan dalam hand sanitizer pada umumnya berupa triklosan dengan kadar 0,05\% sampai dengan $2 \%$. Triklosan dapat memperlambat pertumbuhan bakteri juga bersifat antijamur dan antivirus serta bersifat kurang korosif. Berdasarkan penelitian Fitri (2016) bahwa pada berbagai merk sabun, 
diameter zona hambat yang lebih besar terdapat pada sabun D karena mengandung triklosan dan triklocarban juga menggunakan benzil alkohol sebagai bahan utamanya.

Apabila antiseptik atau handsanitizer digunakan berlebihan dan terus menerus dapat berbahaya dan mengakibatkan iritasi hingga menimbulkan rasa terbakar pada kulit. Karena mengingat bahan dasar antiseptik tersebut berupa alkohol dan triklosan yang merupakan bahan kimia.

Salah satu upaya untuk mengurangi pemakaian bahan kimia berupa alkohol dan triklosan yang terkandung dalam produk antiseptik handsanitizer, maka dilakukan inovasi produk antiseptik handsanitizer dengan menggunakan ekstrak tanaman yang ada di alam yang mengandung sifat antibakteri, misalnya daun mangga, daun serai, dan batang pisang.

Kandungan senyawa yang terdapat pada batang tanaman pisang berupa senyawa metabolit sekunder yang kompleks, yang bersifat antibakteri. Menurut hasil penelitian Apriasari (2013) bahwa batang pisang mauli berpengaruh pada bakteriostatik terhadap Streptococcus mutans paling efektif pada konsentrasi 25\%. Berdasarkan hasil uji fitokimia dengan menggunakan pelarut etanol, batang pisang ambon positif mengandung adanya flavonoid, saponin, dan tannin yang bersifat antibakteri (Nugroho, 2016).

Adapun zat yang berperan sebagai antibakteri dalam batang pisang terdiri atas saponin, flavonoid, dan tanin. Saponin mampu berperan sebagai antibakter, sedangkan flavonoid berperan menghambat pertumbuhan jamur yakni dengan menyebabkan gangguan permeabilitas membran sel jamur tersebut. Selain itu, tanin merupakan zat antiseptik alami yang dapat menghambat pertumbuhan bakteri dengan memunculkan denaturasi protein dan menurunkan tegangan permukaan.

Oleh karena itu batang tanaman pisang dapat dimanfaatkan sebagai bahan dasar pembuatan antiseptik handsanitizer. Hal tersebut juga dikuatkan hasil penelitian Fadhilah, (2017) yang menunjukkan bahwa ekstrak dari batang daun pisang kepok dapat mengurangi jumlah bakteri secara konstan dalam jangka waktu yang lebih lama dibandingkan dengan handsanitizer merk A.

Produk handsanitizer ada yang berbentuk cair dan ada yang berbentukgel. Masyarakat pada umumnya menyukai penggunaan handsanitizer dalam bentuk gel karena menimbulkan rasa dingin dikulit dan mudah mengering. Bahan sediaan gel tersebut yang biasa digunakan adalah carbopol 94, sebab mempunyai stabilitas tinggi dan toksisitasnya rendah, sehingga dapat meningkatkan efektivitas penggunaan gel sebagai antibakteri. Hal tersebut sesuai dengan hasil penelitian Astuti, dkk (2015) bahwa gel antiseptik tangan dengan penambahan carbopol 940 menghasilkan warna sediaan putih, bentuk sediaan gel semisolid, $\mathrm{pH}$ 4,6-6,3 dan viskositas sekitar 2000-4000 cps.

$\mathrm{pH}$ antiseptik handsanitizer perlu diperhatikan karena bila tidak optimal dapat menimbulkan iritasi pada kulit. $\mathrm{pH}$ optimal untuk pembuatan handsanitizer harus sesuai dengan $\mathrm{pH}$ kulit yang berkisar diantara 4,56,5 (Ismail, 2013). Untuk menyelaraskan supaya $\mathrm{pH}$ antiseptik handsanitizer optimal maka perlu adanya penambahan bahan lain yaitu Triethanolamine (TEA) dan Gliserin. TEA bersifat sebagai stabilitas gel yang dapat menyeimbangkan $\mathrm{pH}$ sediaan. TEA memiliki pH 10,5 dan larut dalam air, metanol, karbon tetraklorida, dan aseton.

Sedangkan gliserin dapat menyebabkan sediaan bersifat jernih dan transparan, selain itu gliserin bersifat emollient gel yakni membantu sediaan handsanitizer ketika digunakan pada tangan tidak terlalu kering, dan bersifat sebagai antimikroba. Menurut hasil penelitian Wijaya, (2013) bahwa gliserin berfungsi sebagai penahan lembab yang dapat meningkatkan daya sebar sediaan dan melindungi sediaan dari kemungkinan menjadi kering.

Berdasarkan latar belakang di atas maka yang menjadi permasalahan dalam penelitian ini adalah: bagaimana kualitas (daya hambat bakteri dan tingkat viskositas) dari handsanitizer dalam bentuk gel berbahan batang pisang 
dengan penambahan alkohol, triklosan dan gliserin?

Adapun tujuan yang akan dicapai pada penelitian ini adalah untuk mengetahui untuk mengetahui kualitas (daya hambat bakteri dan tingkat viskositas) dari handsanitizer dalam bentuk gel berbahan batang pisang dengan penambahan triethanolamine dan gliserin.

\section{Metode Penelitian}

Penelitian telah dilaksanakan pada Bulan Maret-Juli 2018 di Laboratorium BiokimiaProdi. Pend. Biologi UMS, dan Uji daya hambat bakteri di Laboratorium Kultur Jaringan Universitas Muhammadiyah Surakarta. Uji viskositas di Laboratorium Teknik Kimia Universitas Muhammadiyah Surakarta. Metode penelitian yang digunakan adalah metode penelitian eksperimental. Rancangan lingkungan yang digunakan Rancangan Acak Lengkap (RAL) dengan pola faktorial dan dua ulangan. Penelitian digunakan 2 faktor, yaitu:

Faktor perlakuan 1 Perbandingan konsentrasi alkohol dan triklosan :

$A_{1}=2 \mathrm{ml}: 1,75 \mathrm{~g}$

$A_{2}=1 \mathrm{ml}: 1,5 \mathrm{~g}$

Faktor perlakuan 2 Volume gliserin :

$K_{1}=4 \mathrm{ml}$

$K_{2}=3 \mathrm{ml}$
$K_{3}=2 \mathrm{ml}$

Adapun Prosedur Penelitian meliputi: a). Tahap persiapan, b). Tahap pelaksanaan pembuatan ekstrak batang pisang sebagai gel handsanitizer alami dengan metode maserasi, c). Tahap pengujian untuk Uji daya hambat bakteri menggunakan metode replika tanpa pengulangan dan untuk Uji Viskositas dengan diukur dengan alat viscometer Brookfield yang dilengkapi dengan spindle no 6 pada kecepatan $20 \mathrm{rpm}$.

Dalam penelitian ini, analisis yang digunakan adalah deskriptif kualitatif yang digunakan untuk melakukan untuk Uji daya hambat bakteri dan untuk Uji Viskositas.

\section{Hasil Penelitian}

Berdasarkan hasil penelitian Kualitas Gel Pembersih Tangan (Handsanitizer) dari Ekstrak Batang Pisang dengan Penambahan Alkohol, Triklosan dan Gliserin yang Berbeda Dosisnya diperoleh data hasil uji daya hambat bakteri dan untuk uji Viskositas sebagai berikut:

\section{Uji Daya Hambat Bakteri}

Hasil pembuatan ekstrak batang pisang sebagai gel handsanitizer alami dengan menggunakan metode replika tanpa pengulangan, menunjukkan adanya pengaruh penurunan jumlah koloni bakteri setelah pengaplikasian gel handsanitizer.

Tabel 1 Uji Daya Hambat Bakteri Sebelum dan Setelah Aplikasi Menggunakan Gel Handsanitizer Batang Pisang dengan Penambahan Alkohol, Triklosan dan Gliserin

\begin{tabular}{ccc}
\hline Perlakuan & \multicolumn{2}{c}{ Jumlah koloni } \\
\cline { 2 - 3 } & $\begin{array}{c}\text { Sebelum pengaplikasian } \\
\text { handsanitizer }\end{array}$ & $\begin{array}{c}\text { Setelah pengaplikasian } \\
\text { handsanitizer }\end{array}$ \\
\hline$A_{1} K_{1}$ & 4 & 0 \\
$A_{1} K_{2}$ & 35 & 0 \\
$A_{1} K_{3}$ & 6 & 3 \\
$A_{2} K_{1}$ & 26 & 5 \\
$A_{2} K_{2}$ & 24 & 8 \\
$A_{2} K_{3}$ & 17 & 7 \\
\hline
\end{tabular}


Berdasarkan hasil pengujian yang dilihat Tabel 1 dari jumlah koloni sebelum dan sesudah pengaplikasian gel handsanitizer pada jari tangan menunjukkan adanya pengurangan jumlah koloni bakteri pada setiap perlakuan. Pengaplikasian gel handsanitizer paling optimal terlihat pada perlakuan.

\section{Uji Viskositas}

Hasil uji viskositas gel handsanitizer batang pisang dilakukan dengan menggunakan metode viskometer cup and bop dari enam sampel perlakuan. Hasil akan dibandingkan dengan standart viskositas normal untuk gel handsanitizer yang berkisar antara 20004000cps (Harimurti, 2016).

Tabel 2 Uji Viskositas Terhadap Gel Handsanitizer Batang Pisang dengan Penambahan Alkohol, Triklosan dan Gliserin

\begin{tabular}{ccc}
\hline Perlakuan & Hasil viskositas (cps) & Standart viskositas (cps) \\
\hline$A_{1} K_{1}$ & 750 & $2000-4000$ \\
$A_{1} K_{2}$ & 800 & $2000-4000$ \\
$A_{1} K_{3}$ & 550 & $2000-4000$ \\
$A_{2} K_{1}$ & 520 & $2000-4000$ \\
$A_{2} K_{2}$ & 1250 & $2000-4000$ \\
$A_{2} K_{3}$ & 1000 & $2000-4000$ \\
\hline
\end{tabular}

Berdasarkan tabel diatas hasil viskositas menunjukkan viskositas berada dibawah standart normal pada umumnya, sehingga gel pada handsanitizer batang pisang memiliki kekentalan yang rendah. Viskositas terendah terdapat pada perlakuan dengan hasil uji sebesar 520 cps, sedangkan viskositas tertinggi terdapat pada perlakuandengan hasil uji viskositas sebesar 1250 cps.

\section{Pembahasan}

Berdasarkan hasil penelitian Kualitas Gel Pembersih Tangan (Handsanitizer) dari Ekstrak Batang Pisang dengan Penambahan Alkohol,
Triklosan dan Gliserin yang Berbeda Dosisnya diperoleh data hasil uji daya hambat bakteri dan untuk uji Viskositas sebagai berikut:

\section{Uji Daya Hambat Bakteri}

Berdasarkan tabel 1 menunjukkan hasil uji daya hambat bakteri dengan menggunakan gel handsanitizer batang pisang sebelum dan setelah pengaplikasian gel pada jari tangan terdapat penurunan jumlah koloni bakteri. Pada gambar grafik 1 di bawah ini menunjukkan pengujian daya hambat bakteri dengan menggunakan air biasa sebagai kontrol membuktikan bahwa air biasa tidak mempunyai efek antibakteri sehingga tidak mempengaruhi hasil uji antibakteri. 


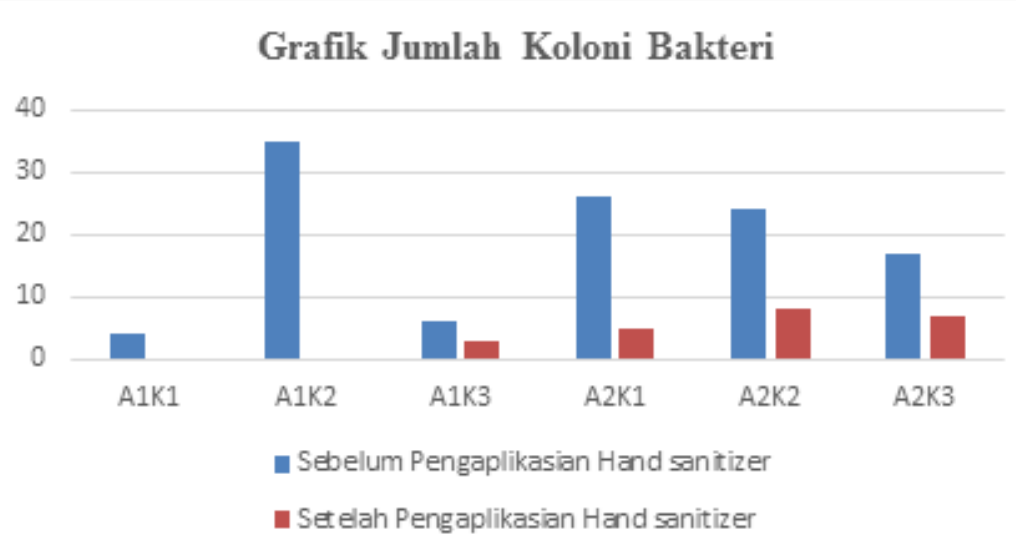

Gambar grafik 1 jumlah koloni bakteri sebelum dan sesudah pengaplikasian gel handsanitizer batang pisang

Hasil penelitian menunjukkan bahwa mencuci tangan menggunakan air biasa tidak mempengaruhi hasil uji bakteri. Hal ini dikarenakan air biasa yang digunakan untuk mencuci jari tangan tidak memiliki kandungan senyawa zat aktif yang mampu membunuh bakteri. Pada perlakuan setelah pengaplikasian handsanitizer dari ekstrak batang tanaman pisang pada jari tangan membuktikan adanya penurunan jumlah koloni bakteri, sehingga membuktikan bahwa terdapatnya senyawa zat aktif pada batang tanaman pisang yang mampu untuk membunuh bakteri.

Bila dilihat pada tabel 1 dan Gambar grafik 1 pada masing-masing perlakuan memiliki hasil uji daya hambat bakteri yang berbedabeda. Bila dilihat menurunnya jumlah koloni bakteri setelah pengaplikasian gel handsanitizer batang pisang pada jari tangan, menunjukkan perlakuan paling efektif yang dapat membunuh bakteri terdapat pada perlakuan dan . Hal tersebut dikarenakan gel handsanitizer batang pisang mempunyai kemampuan antibakteri.

Adanya efek antibakteri pada gel handsanitizer batang pisang tersebut dikarenakan batang pisang mengandung beberapa senyawa kimia yakni flavonoid, saponin dan tanin. Berdasarkan hasil uji fitokimia dengan menggunakan pelarut etanol, batang pisang positif mengandung adanya flavonoid, saponin, dan tannin yang bersifat antibakteri (Nugroho, 2016).
Flavonoid merupakan senyawa aktif yang dapat digunakan sebagai antibakteri, antiflamasi, dan antijamur. Mekanisme flavonoid dalam menghambat pertumbuhan jamur yakni dengan menyebabkan gangguan permeabilitas membran sel jamur. Gugus hidroksil yang terdapat pada senyawa flavonoid menyebabkan perubahan komponen organik dan transport nutrisi yang akhirnya akan mengakibatkan timbulnya efek toksik terhadap jamur.

Begitu pula dengan tanin yang berfungsi untuk menghambat pertumbuhan bakteri dengan memunculkan denaturasi protein dan menurunkan tegangan permukaan, sehingga permeabilitas bakteri meningkat, serta menurunkan konsentrasi ion kalsium, menghambat produksi enzim, dan mengganggu proses reaksi enzimatis pada bakteri (Herry, 2013).

Sedangkan saponin merupakan senyawa metabolik sekunder yang mempunyai fungsi sebagai antiseptik sehingga mampu sebagai antibakteri. Senyawa saponin akan membentuk senyawa kompleks dengan membran sel melalui ikatan hidrogen, sehingga sifat permeabilitas dinding sel dapat dihancurkan dan menimbulkan kematian sel (Nur, 2013).

Hasil dari pengujian daya hambat bakteri dengan pengaplikasian pada jari tangan sebelum dan sesudah menggunakan handsanitizer yang berupa koloni dapat dilihat pada gambar 2 dan gambar 3 berikut ini: 

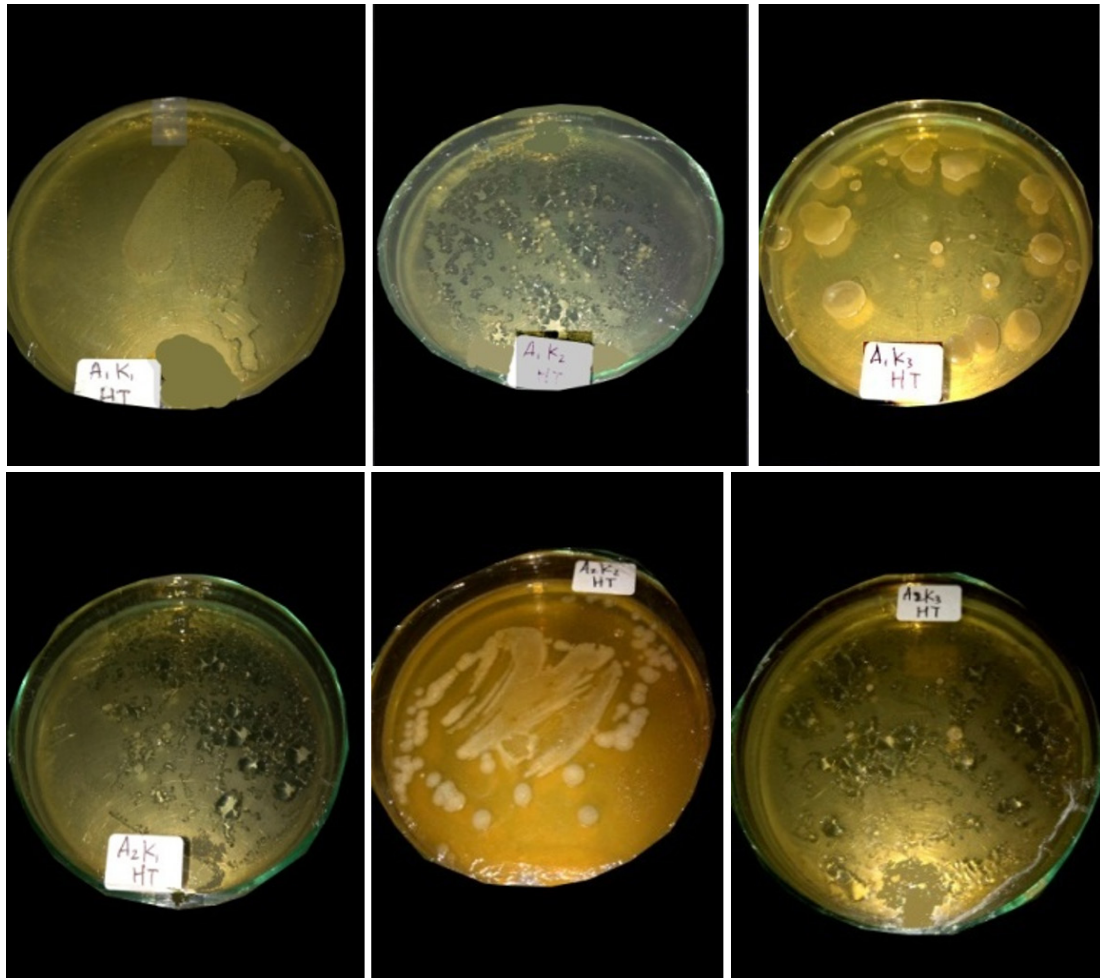

Gambar 2 koloni bakteri sebelum pengaplikasian handsanitizer

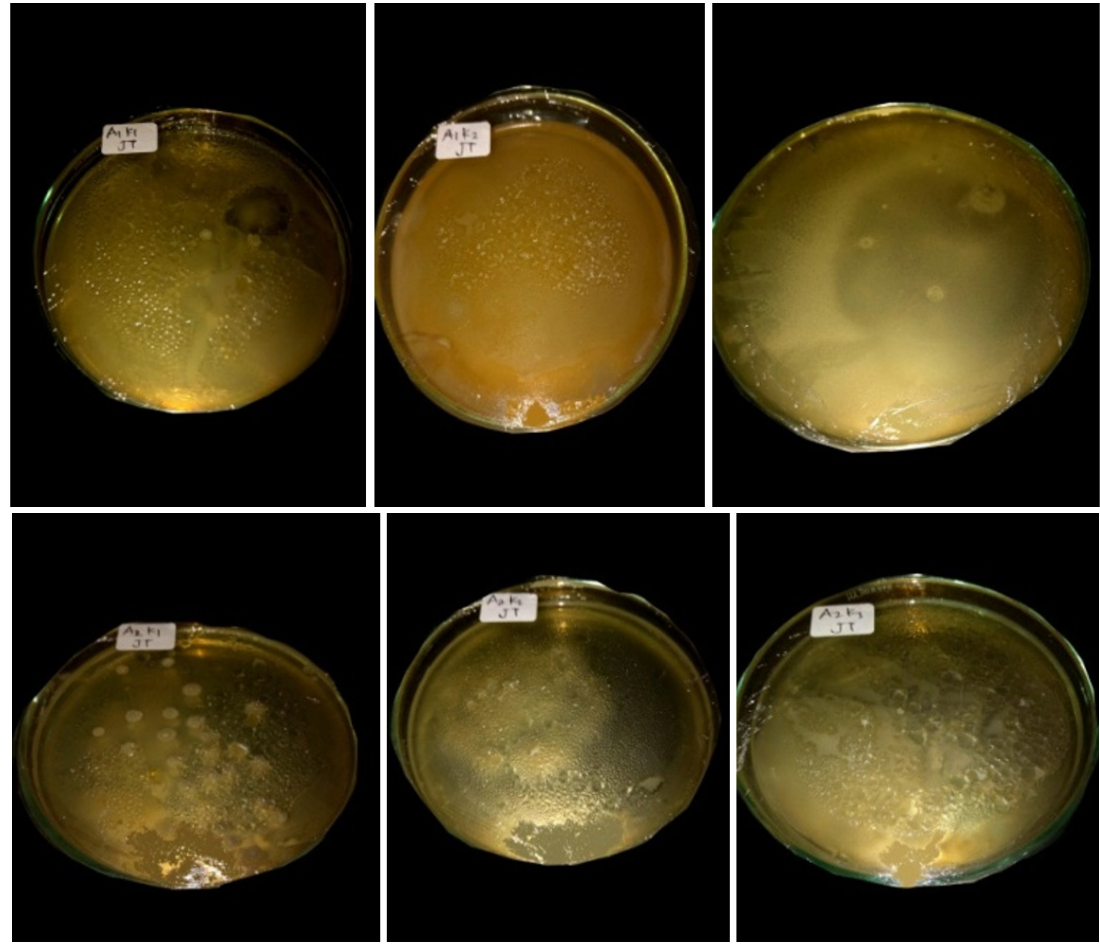

Gambar 3 koloni bakteri sesudah pengaplikasian handsanitizer

Hasil daya hambat bakteri tersebut selain dihambat oleh beberapa senyawa yang ada pada batang pisang juga dikarenakan adanya tambahan pemberian alkohol dan triklosan.
Penambahan alkohol dan triklosan pada gel handsanitizer dapat mempengaruhi penurunan jumlah koloni bakteri ketika digunakan. Hal ini sesuai dengan teori yang menyatakan bahwa 
alkohol mempunyai aktivitas sebagai bakterisid, yang dapat membunuh bakteri dalam bentuk vegetatifnya (Noviansari, 2013). Sedangkan menurut Siswando (1995) alkohol dapat membunuh bakteri gram positif dan gram negatif, termasuk pathogen yang multi drug resistant Mycobacterium tuberculosis, dan virus.

Turunan alkohol dapat menghambat fosforilasi dan efeknya dapat terlihat jelas pada mitokondria, yang dapat menimbulkan denaturasi protein sel bakteri. Sebagai antiseptik alkohol memiliki kelebihan yang mudah menguap, sehingga tidak membutuhkan waktu yang lama untuk mengering ketika diaplikasin ke tangan. Akan tetapi ini juga menjadi kelemahan, karena efektivitasnya hanya jangka pendek, sehingga bakteri hanya dapat dikurangi dalam waktu singkat setelah penggunaan antiseptik (Fadhilah, 2017). Selain itu penggunaan alkohol yang berlebihan juga dapat mengakibatkan iritasi pada kulit, bahkan memiliki efek terbakar.

Sedangkan triklosan efektif untuk membunuh bakteri gram positif maupun gram negatif dengan cara mempengaruhi dinding sel mikroba sehingga integritas dinding sel bakteri terganggu dan menyebabkan sel mengalami lisis. Triklosan tidak efektif dalam membunuh jamur, sehingga perlu adanya kombinasi dengan alkohol yang efektif dalam membunuh jamur. Hasil dari daya hambat bakteri pada masing masing perlakuan yang berbeda tersebut juga dikarenakan karena adanya perbedaan perbandingan konsentrasi alkohol dan triklosan yang diberikan. Pada perlakuan dan memiliki perbandingan konsentrasi penambahan alkohol dan triklosan $2 \mathrm{ml}$ : 1,75 g, sedangkan pada perlakuan, dan $1 \mathrm{ml}: 1,5 \mathrm{~g}$.

\section{Uji Viskositas}

Berdasarkan tabel 2 menunjukkan hasil uji viskositas pada sediaan gel handsanitizer batang pisang dengan penambahan alkohol, triklosan dan gliserin. Hasil yang didapat dengan mengukur sediaan menggunakan viskometer cup and bop menunjukkan hasil viskositas yang rendah. Hasil tersebut juga dapat dilihat pada gambar 4 berikut ini.

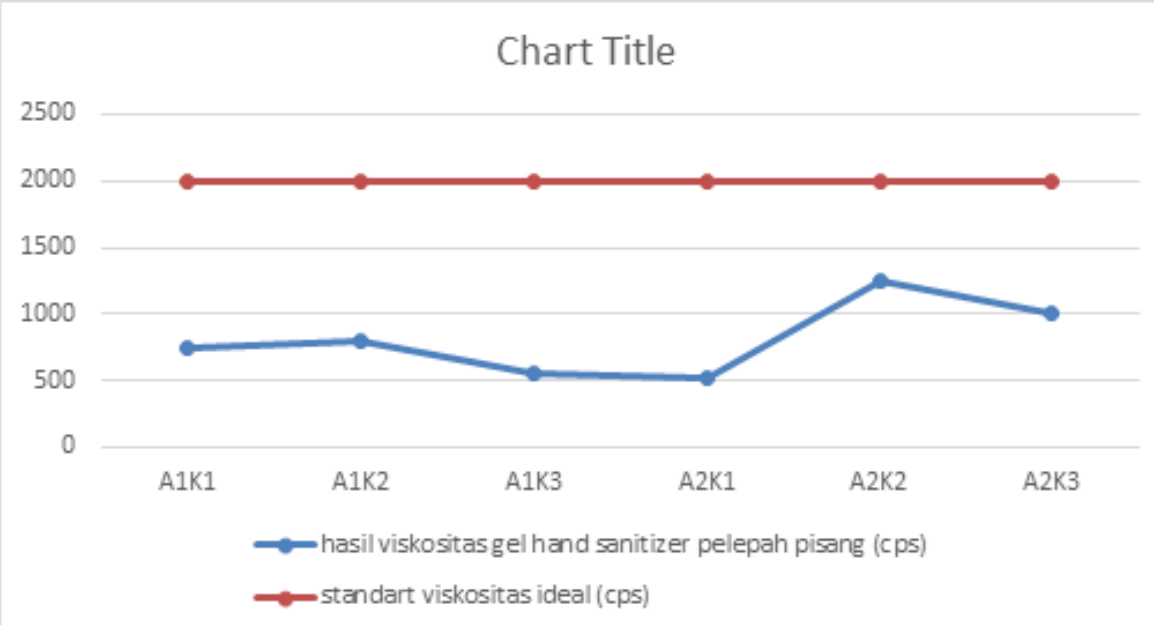

Gambar grafik 4. hasil uji viskositas gel hand sanitizer batang pisang

Berdasarkan Gambar grafik 4 diatas menunjukkan bahwa hasil uji viskositas berada dibawah standart viskositas normal, karena viskositas standart (cps) menurut Harimurti, (2016) yaitu berkisar antara 2000-4000cps. Hasil viskositas atau tingkat kekentalan gel hand sanitizer rendah, kemungkinan bisa disebabkan faktor non teknis dalam pengujian yang memakan waktu lama (2 minggu), sehingga kekentalan gel mengalami sedikit cair. Dari setiap perlakuan menunjukkan hasil vikositas yang berbeda, hasil viskositas terendah terdapat 
pada perlakuan dengan nilai viskositas sebesar 520 cps, sedangkan viskositas tertinggi terdapat pada perlakuan dengan nilai viskositas sebesar 1250cps.

Pada pembuatan handsanitiser batang tanaman pisang ada penambahan carbomer dan gliserin pada sediaan yang fungsinya dapat meningkatkan kekentalan pada gel. Semakin tinggi penambahan konsentrasi basis gel maka semakin tinggi pula viskositas yang dihasilkan. Carbomer dan gliserin dapat meningkatkan viskositas.

Carbomer merupakan agen pengental yang berfungsi untuk meningkatkan viskositas dan gliserin berfungsi untuk menjaga kandungan lembab pada sediaan, dan memiliki fungsi lainnya yaitu sebagai agen pengental sehingga dengan penggunaan carbomer dan gliserin yang besar dapat meningkatkan viskositas dari sediaan gel dan sebaliknya (Jessica, 2012). Carbomer merupakan basis gel yang baik karena memiliki viskositas 40.000-60.000 cps (Jessica, 2012). Akan tetapi semakin besar konsentrasi karbomer dapat menurunkan $\mathrm{pH}$ pada sediaan gel handsanitizer sehingga bersifat asam (Harimurti, 2016).

Vikositas sediaan yang dihasilkan berada dibawah standart normal viskositas untuk handsanitizer dapat juga dikarenakan beberapa faktor, yaitu $\mathrm{pH}$, carbomer, $\mathrm{pH}$ ekstrak, dan jumlah triethanolamine yang digunakan. Berdasarkan penelitian Harimurti (2016), hasil vikositas yang rendah dikarenakan beberapa faktor, yaitu $\mathrm{pH}$, carbomer, $\mathrm{pH}$ ekstrak, dan jumlah triethanolamine yang digunakan.

Pada sediaan gel handsanitizer batang pisang memiliki $\mathrm{pH}$ 5,5 yang berarti bersifat sedikit asam, akan tetapi optimal untuk $\mathrm{pH}$ kulit yang berkisar antara 4,5-6,5. Nilai $\mathrm{pH}$ yang bersifat asam tersebut dapat mengakibatkan penurunan viskositas sediaan gel. Hal ini dapat mempengaruhi jumlah gugus karboksil terion berkurang sehingga tolak-menolak pada gugus karboksil yang dapat menyebabkan pengembangan struktur karbomer menurun. Dengan demikian dapat menyebabkan penurunan viskositas sediaan gel (Harimurti, 2016).

Selain itu dapat juga dikarenakan suhu dan waktu penyimpanan yang semakin lama akan semakin menurunkan viskositas. Hal tsb disebabkan sediaan gel menunjukkan karakteristik synersis yang merupakan proses keluarnya cairan yang terjerat dalam gel sehingga memungkinkan cairan untuk bergerak menuju permukaan. Oleh karena itu sediaan mengalami penurunan viskositas (Astuti, 2015).

Sediaan gel handsanitizer batang pisang yang masuk dalam rentang nilai viskositas yang mendekati standart normal adalah perlakuan - Sedangkan untuk formula yang lainnya walaupun tidak memenuhi nilai viskositas yang ideal tetap menunjukkan kestabilan yang baik. Semakin besar viskositas suatu fluida maka semakin sulit suatu benda bergerak dalam fluida. Dalam hal ini semakin kental sediaan gel, maka akan semakin besar kekuatan yang diperlukan sediaan gel tersebut untuk dapat mengalir dengan kecepatan tertentu, dan sebaliknya (Harimurti, 2016).

\section{Simpulan}

Ada perbedaan kualitas (daya hambat bakteri dan tingkat viskositas) dari handsanitizer dalam bentuk gel berbahan batang pisang dengan penambahan alkohol, triklosan dan gliserin. Daya hambat paling tinggi pada perlakuan dengan Perbandingan konsentrasi alkohol $2 \mathrm{ml}$ dan triklosan $1,75 \mathrm{~g}$ dengan gliserin $4 \mathrm{ml}$ dan tingkat viskositas paling tinggi pada perlakuan dengan Perbandingan konsentrasi alkohol $1 \mathrm{ml}$ dan triklosan 1,5 g dengan gliserin $3 \mathrm{ml}$. 


\section{Daftar Pustaka}

Apriasari, M. L. 2013. "Aktivitas Antibakteri Ekstrak Metanol Batang Pisang Mauli (Musa sp.) terhadap Streptococcus mutans". Dentofasial, 12(3), 148-151.

Astuti, D. P. , Husni, P. , Hartono, K. (2015). Formulasi dan Uji Stabilitas Fisik Sediaan Gel Antiseptik Tangan Minyak Atsiri Bunga Lavender (Lavanda angustifolia miller). Farmaka, 15(1), 176-184.

Burt, S. (2004). Essential Oils : Their Antibacterial Properties and Potential Application in FoodsA Review, Int. J. Food Microbiology, (4 (3) : 223-253.

Damayanti, A. , \& Fitriana, E. A. (2012). Pemungutan Minyak Atsiri Mawar (Rose Oil) Dengan Metode Maserasi. Jurnal Bahan Alam Terbarukan, 1(2), 1-8.

Fadhilah, N. L. (2017). Potensi Pelepah Daun Pisang Kepok Sebagai Handsanitizer Alami. Biologi, $2(5), 1-8$.

Fitri, L. (2016). Kemampuan Daya Hambat Beberapa Macam Sabun Antiseptik Terhadap Pertumbuhan Staphylococcus aureus dan Escherichia coli. Biology, 1(2), 1-7.

Harimurti, S., Hidayaturahmah, R. (2016). Pengaruh Variasi Konsentrasi Karbomer Sebagai Gelling Agent Terhadap Viskositas dan pH Sediaan Gel Antiseptik Ekstrak Etanolik Daun Sirih Merah. FKIK, 1(5), 1-8.

Herrry M. S., Amy Nindia C., Maharani Laillyza A. (2013). Uji Efektivitas Antifungi Ekstrak Metanol Batang Pisang Mauli terhadap Candida albicans.Jurnal PDGI. Vol. 62; 7-10.

Ismail, I. (2013). Formulasi Kosmetik (Produk Perawatan Kulit dan Rambut. Makassar : Universitas Alauddin Press.

Jessica. (2012). Optimasi Formula Gel Hand Sanitizer Minyak Atsiri Jeruk Bergamot dengan Kombinasi CMC Na dan Gliserin. Skripsi, Universitas Sanata Dharma, 1-108.

Lachman L., Libermen H. A., \& Kaning J. L. (2004). Theori and Practise of Industrial Pharmacy. Easton Pennysylvania : Mack Publishing Company.

Nopitasari. (2018). Pemanfaatan Pelepah Pisang Sebagai Bahan Pembuatan Hand Sanitizer dalam Bentuk Gel dengan Penambahan Alkohol dan Triklosan. Publikasi Ilmiah, Universitas Muhammadiyah Surakarta, 1-9.

Nugroho, K. M. 2016. "Isolasi Senyawa Bioaktif Batang Pisang Ambon (Musa paradisiaca Var. Sapientum) sebagai Bahan Baku Antibakteri”. Indo. J. Chem. Sci., 5(3), 206-210.

Noviansari, R., Sudarmin, Siadi, K. (2013). Transformasi Metil Eugenol Menjadi 3-(3,4 DimetoksiFenil)-1-Propanol dan Uji Aktivitasnya Sebagai Antibakteri.Jurnal Jurusan Kimia FMIPA, Universitas Negeri Semarang. 2(2).

Nur, J et al. (2013). Bioaktivitas Getah Pelepah Pisang Ambon Musa paradisiaca L. var Sapientum terhadap Pertumbuhan Bakteri Staphylococcus aureus, Pseudomonas aeroginosa dan Escherichia coli. Skripsi. Fakultas Biologi, Universitas Hasanuddin.

Rini, E. P., \& Nugraheni E. R. (2018). Uji Daya Hambat Berbagai Merek Handsanitizer Gel Terhadap Pertumbuhan Bakteri Escherichia coli dan Staphylococcus aureus. Journal of Pharmaceutical Science and Clinical Research, 1(10), 18-26.

Rowe, R. C. (2009). Handbook of Pharmaceutical Excipients e-book Pharmaceutical. USA : American 
Pharmatic Assosiation Press.

Septian, D. (2012). Perbandingan Variasi Jumlah Triethanolamine Terhadap Stabilitas Sifat Fisik Dan Sifat Kimia Gel Antiseptik Ekstrak Bunga Rosella (Hibiscus sabdariffa L.). FMIPA, 3(1), 2-3.

Shu, M. (2013). Formulasi Sediaan Gel Handsanitizer Dengan Bahan Aktif Triklosan 0,5\% Dan 1\%. Jurnal Ilmiah Mahasiswa Universitas Surabaya, 2(1), 1-14.

Verica, S. P. (2014). Pengaruh Konsentrasi Carbopol 940 Sebagai Gelling Agent Terhadap Sifat Fisik Dan Stabilitas Gel Handsanitizer Minyak Daun Mint (Oleum mentha piperita). Yogyakarta : Universitas Sanata Dharma.

World Health Organization. (2005). Guidelines for Handsanitizer Formulation Design and Drug Delivery. Singapore : John Wiley and Sons.

Wijaya, J. I. (2013). Formulasi Sediaan Gel Handsanitizer Dengan Bahan Aktif Triklosan 1,5\% dan 2\%. Jurnal Ilmiah Mahasiswa Universitas Surabaya, 2(1), 1-14. 